\title{
Penggunaan Antibiotik Secara Bijak Untuk Mengurangi Resistensi Antibiotik, Studi Intervensi di Bagian Kesehatan Anak RS Dr. Kariadi
}

\author{
Helmia Farida*, Herawati**, MM Hapsari**, Harsoyo Notoatmodjo**, Hardian ${ }^{* * *}$ \\ * Bagian Mikrobiologi Klinik FK Undip/ RS Dr. Kariadi \\ ** Bagian Ilmu Kesehatan Anak FK Undip/ RS Dr. Kariadi \\ *** Central Biostatistic Unit FK Undip
}

\begin{abstract}
Latar belakang. Masalah resistensi antibiotik di Indonesia sudah mengkhawatirkan. Penggunaan antibiotik secara bijak merupakan kunci utama pengendalian resistensi.

Tujuan. Penelitian bertujuan meneliti faktor-faktor yang mempengaruhi kualitas penggunaan antibiotik di Bangsal Kesehatan Anak RS Dr. Kariadi dan menguji apakah kualitas dapat ditingkatkan dengan pelatihan.

Metode. One group pretest and post test subjek adalah 22 dokter yang merawat pasien kelas III, mengikuti pelatihan penggunaan antibiotik, dan dapat ditelusuri resep antibiotik yang dibuatnya dalam 6 bulan sebelum dan sesudah pelatihan. Variabel tergantung adalah skor kualitas penggunaan antibiotik berdasarkan modifikasi Kunin dan Gyssen. Variabel bebas adalah pelatihan, pengetahuan, sikap, faktor pendorong, dan faktor penghambat. Pengetahuan dan sikap diukur dengan kuesioner. Analisis statistik bivariat menggunakan Uji $\chi^{2}$ dan Mann-Whitney. Analisis multivariat untuk mengukur besarnya pengaruh pelatihan dan faktorfaktor lain terhadap kualitas peresepan antibiotik dengan GEE.

Hasil. Diantara 1365 resep antibiotik yang dievaluasi didapatkan penggunaan antibiotik tanpa indikasi setelah pelatihan berkurang dari $42.3 \%$ menjadi $23,2 \%$, dan penggunaan antibiotik yang tepat meningkat dari $36,2 \%$ menjadi 58,2\%. Rerata skor kualitas pengunaan antibiotik meningkat dari 2,0 menjadi 2,8. Perubahanperubahan ini bermakna $(p<0,05)$. Pelatihan berperan besar dalam meningkatkan kualitas penggunaan dokter, faktor-faktor lain tidak memiliki pengaruh yang bermakna terhadap kualitas penggunaan antibiotik. Kesimpulan. Pelatihan yang efektif dapat meningkatkan kualitas penggunaan antibiotik.(Sari Pediatri 2008;10(1):34-41).
\end{abstract}

Kata Kunci: kualitas penggunaan antibiotik, anak, demam

Alamat Korespondensi:

Dr. Helmia Farida., Sp A. Bagian Ilmu Kesehatan Anak FK Undip/ RS

Dr. Kariadi Jl. Dr. Soetomo 16-18 Semarang. Telp. 024-8414296. 
P enemuan dan penggunaan antibiotik secara luas dalam bidang kesehatan sejak 1943 telah berhasil menurunan angka kesakitan dan kematian akibat infeksi secara tajam. Keadaan ini mendorong penggunaan antibiotik yang berlebihan sehingga hanya dalam 4 tahun kemudian telah timbul problem resistensi dengan segala akibat yang sangat merugikan., ${ }^{1,2}$ Resistensi antibiotik sudah menjadi pandemi global dan salah satu kecemasan dunia yang terbesar. ${ }^{4}$

RS Dr Kariadi sebagai rumah sakit besar juga menghadapi masalah resistensi antibiotik. Data 2002 menunjukkan bahwa semua isolat dari darah memiliki tingkat multiresistensi tinggi terhadap antibiotik, ${ }^{5}$ dan $45 \%-56 \%$ penggunaan antibiotik irasional. ${ }^{6}$

Bayi dan anak lebih sering sakit sehingga lebih berisiko mendapatkan antibiotik yang kurang tepat. Kekhawatiran tidak dapat membedakan infeksi bakterial dari sebab lain demam merupakan alasan utama dokter memberikan antibiotik pada hampir semua anak demam. Peri laku dokter dan orang tua dari anak penting dalam problem resistensi antibiotik. ${ }^{7,8}$
Penelitian bertujuan mengukur kualitas penggunaan antibiotik pada pasien dengan demam di Bangsal Anak FK RS Dr. Kariadi, faktor-faktor yang mempengaruhinya, dan menguji apakah kualitas penggunaan antibiotik tersebut dapat ditingkatkan dengan pelatihan.

\section{Metode}

Penelitian ini merupakan bagian proyek penelitian AMRIN (antimicrobial resistance in Indonesia, prevention and prevalence) fase II, dilakukan di Bangsal Anak RS Dr. Kariadi, Desember 2003 -Nopember 2004, dengan desain one group pre and post test. Subjek 22 dokter Bangsal Anak RS Dr. Kariadi, mengikuti pelatihan penggunaan antibiotik yang tepat (PAT), dan dapat ditelusuri resep antibiotik yang dibuatnya dalam 6 bulan sebelum dan sesudah pelatihan untuk pasien umur 1 bulan-12 tahun yang dirawat dengan demam.

Variabel tergantung adalah skor kualitas penggunaan antibiotik berdasarkan kesesuaian dengan

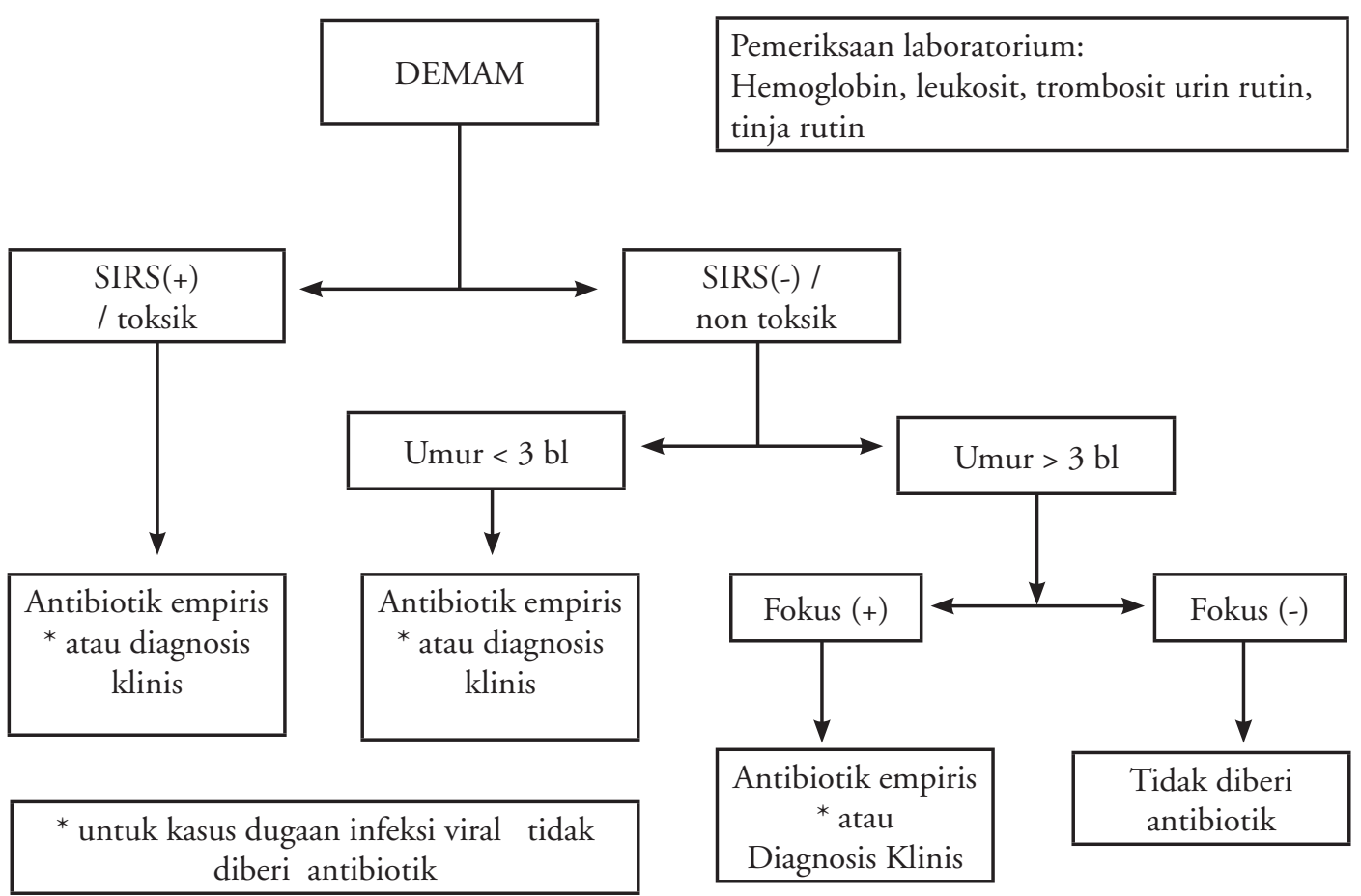

Gambar 1. Algoritme pemberian antibiotik pada pasien demam

Keterangan: SIRS = systemic inflammatory response syndrome 
algoritme yang diperkenalkan dalam pelatihan PAT (Diagram 1). Skor dinilai oleh seorang dokter spesialis anak dan seorang dokter spesialis mikrobiologi klinik berdasarkan modifikasi Kunin dan Gyssen. ${ }^{9}$ Skor 0 bila antibiotik diberikan tanpa indikasi, 1 bila antibiotik diresepkan tepat indikasi, tetapi tidak tepat dosis/ interval/ rute pemberian, 2 bila antibiotik diresepkan tepat indikasi, dosis/ interval/ rute pemberian tetapi tidak tepat dalam lama pemberian, 3 bila antibiotik diresepkan tepat indikasi, tepat, dosis/interval/rute, dan lama pemberian tetapi tidak tepat jenisnya, skor 4 bila antibiotik diresepkan tepat indikasi, dosis/ interval/rute, lama pemberian dan jenisnya, atau tidak diberikan antibiotik pada kasus yang memang tidak perlu antibiotik. Variabel bebas adalah pelatihan, pengetahuan, sikap, tingkat kesulitan kasus, faktor pendorong, dan faktor penghambat.

Pengetahuan dan sikap diukur dengan kuesioner yang disusun bersama dengan seorang dokter spesialis Anak, spesialis Penyakit Dalam, dan psikolog. Validitas kuesioner diukur dengan expert validity. Reliabilitas data diuji dengan Kuder-Richardson untuk "Kuesioner Pengetahuan" dan dengan Cronbach-alfa untuk "Kuesioner Sikap". Kualitas penggunaan antibiotik dinilai 6 bulan sebelum dan setelah pelatihan. Kuesioner pengetahuan diisi oleh subjek penelitian sebelum dan sesudah pelatihan. Kuesioner sikap diisi melalui wawancara oleh petugas satu minggu sebelum dan satu minggu sesudah pelatihan. Pelatihan dilakukan selama dua hari dengan metode ceramah dan diskusi kelompok terarah, dilanjutkan dengan umpan balik selama satu hari satu bulan kemudian. Materi pokok pelatihan adalah algoritme pemberian antibiotik sebelum ada hasil biakan pada anak dengan demam (Gambar 1).

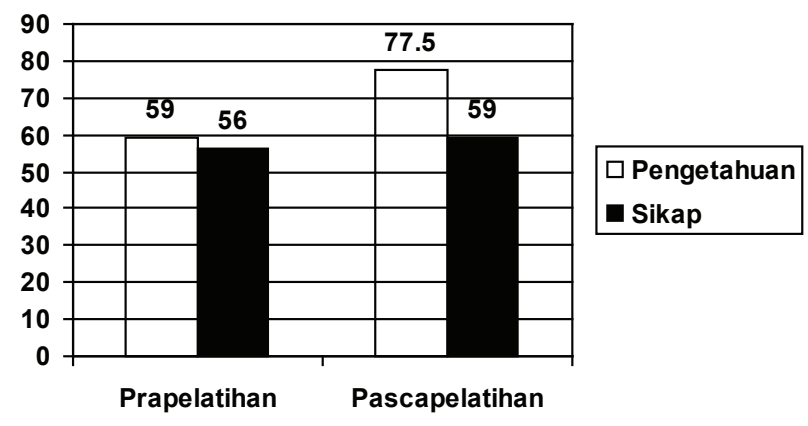

Gambar 2. Perubahan skor pengetahuan sebelum dan sesudah pelatihan
Perbedaan kualitas penggunaan antibiotik sebelum dan sesudah pelatihan diuji dengan Uji $\chi^{2}$. Rerata skor diuji dengan Mann-Whitney. Besarnya pengaruh pelatihan dan faktor lain terhadap kualitas terapi antibiotik dianalisis dengan GEE (generalized estimating equation).

\section{Hasil}

\section{Karakteristik subjek penelitian}

Pengetahuan dan sikap dokter sebelum dan sesudah pelatihan

Validitas Kuesioner Pengetahuan sebesar 0,9; dan koefisien reliabilitasnya 0,9. Validitas Kuesioner Sikap adalah 0,9 , dan koefisien reliabilitasnya 0,8 . Skor pengetahuan dan sikap dokter tentang antibiotik ditampilkan pada Gambar 2.

Gambar 2 menunjukkan bahwa terjadi perubahan bermakna pada pengetahuan dan sikap dokter sesudah pelatihan. Untuk skor pengetahuan, selain terjadi peningkatan nilai absolut (dari 59,0 menjadi 77,5) juga terjadi peningkatan dari kategori kurang menjadi kategori baik. Untuk skor sikap, walaupun secara

Tabel 1. Persepsi dokter mengenai faktor- faktor yang mempengaruhi kualitas penggunaan antibiotik

\begin{tabular}{lcc}
\hline Faktor yang berpengaruh & Jumlah & $\%$ \\
\hline Keyakinan manfaat pelatihan & 16 & 72,7 \\
$\quad$ - tidak & & \\
$\begin{array}{l}\text { Pengaruh teman sejawat } \\
\quad \text { - tidak ada }\end{array}$ & 9 & 40,9 \\
$\begin{array}{l}\text { Pengaruh supervisi } \\
\quad \text { - tidak ada }\end{array}$ & 17 & 77,3 \\
Pengaruh produsen farmasi & 4 & 18,2 \\
$\quad$ - tidak ada/kecil & 18 & \\
$\quad$ - ada/besar & & \\
Ketersediaan obat & 2 & 9,9 \\
$\quad$ - tidak ada/kecil & 20 & \\
Diskusi dengan teman sejawat & 7 & 31,8 \\
$\quad$ - tidak ada & 15 & \\
Diskusi dengan supervisor & 9 & 40.9 \\
$\quad$ - tidak ada/jarang & 13 & \\
Diskusi ilmiah & 7 & 31,8 \\
$\quad$ - tidak ada & & 31,8 \\
Kehadiran peneliti & 7 & \\
- tidak ada & & \\
\hline
\end{tabular}


statistik meningkat bermakna secara substansi dapat dikatakan tidak bermakna, karena skor pra maupun pasca pelatihan sudah masuk kategori sikap yang positif terhadap penggunaan antibiotik yang rasional.

Persepsi dokter mengenai faktor mempengaruhinya dalam peresepan antibiotik. Dari Tabel 1 tampak bahwa sebagian besar subjek meyakini manfaat pelatihan dalam mengelola pasien secara lebih baik, khususnya dalam penggunaan antibiotik. Sebagian besar subjek $(77,3 \% 0)$ mengaku sangat dipengaruhi oleh supervisi dalam menetapkan peresepan antibiotik; meskipun demikian hanya $40,9 \%$ subjek yang merasa mendapatkan supervisi langsung mengenai penggunaan antibiotik. Adapun peran sejawat, produsen farmasi, ketersediaan obat, keluarga pasien, perawat serta kehadiran peneliti (power distance) pada umumnya tidak dianggap sebagai faktor yang berpengaruh.

\section{Kualitas (perilaku) penggunaan antibiotik}

Selama periode penelitian terdapat terdapat 267 pasien yang memenuhi kriteria untuk dievaluasi kualitas penggunaan antibiotik, mencakup 1365 resep yang memenuhi syarat yang dibuat subjek penelitian. Penilaian kualitas penggunaan antibiotik oleh dua observer secara independen berdasar Gambar 1 menunjukkan Kappa lebih dari 0,8. Perubahan kualitas penggunaan antibiotik sebelum dan sesudah pelatihan ditampilkan pada Gambar 3.

Gambar 3 menunjukkan penggunaan antibiotiktanpa-indikasi (Skor 0) berkurang secara bermakna $(\mathrm{p}<0,05)$ dari $42,7 \%$ menjadi $23,3 \%$. Penggunaan antibiotik yang tepat (Skor 4) meningkat secara bermakna dari $36,3 \%$ menjadi $58,2 \%(p<0,05)$.
Rerata skor penggunaan antibiotik meningkat dari 2,0 (SD 0,6) menjadi 2,8 (SD 0,4) $(p<0,01)$. Ini berarti peningkatan skor terutama disebabkan karena berkurangnya Skor 0 (antibiotik-tanpa-indikasi) dan meningkatnya skor 4 (penggunaan antibiotik yang tepat).

Tinjauan lebih rinci kualitas penggunaan antibiotik menurut diagnosis infeksi ditampilkan pada Tabel 2. Pada hampir semua kasus penyakit terjadi peningkatan skor secara bermakna. Pada pnemonia skor kualitas justru menurun dari 3,4 menjadi 2,8. Hal ini karena pada pasca-pelatihan terdapat 11 resep dengan skor 0 , berupa kombinasi sefotaksim dan kloramfenikol (pada fase prapelatihan kombinasi tersebut tidak pernah digunakan). Sebenarnya kombinasi yang keliru tersebut juga terjadi pada kasus meningitis yaitu 17 kasus prapelatihan dan 15 kasus pascapelatihan, namun karena pasca pelatihan proporsi resep dengan skor 1 berkurang dan resep dengan skor 4 meningkat maka rerata skor pada meningitis tetap meningkat secara bermakna, meski nilai absolutnya masih rendah ( dari 1,6 menjadi 2,2 pada pasca pelatihan).
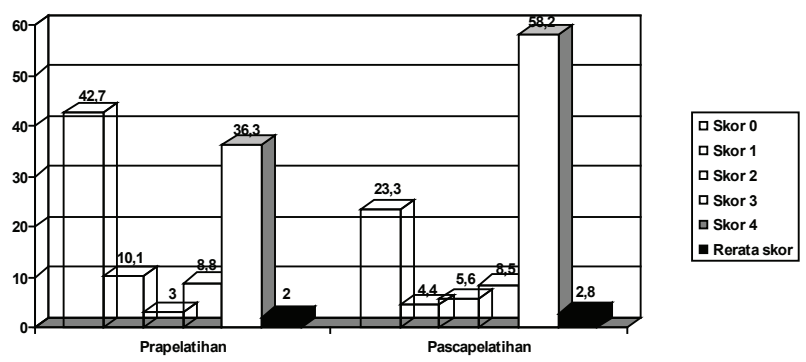

Gambar 3. Skor kualitas penggunaan antibiotik

Tabel 2. Perbandingan kualitas penggunaan antibiotik menurut diagnosis infeksi

\begin{tabular}{lccc}
\hline Diagnosis infeksi & \multicolumn{3}{c}{ Rerata skor kualitas (SD) } \\
\cline { 2 - 4 } & Pra-pelatihan & Pasca-pelatihan & $p$ \\
\hline Pneumonia & $3.4(0,99)$ & $2,8(1,08)$ & $<0,001$ \\
Gastroenteritis & $2.0(0,92)$ & $3.1(0,56)$ & 0,04 \\
Meningitis & $1.6(0,47)$ & $2.2(0,79)$ & 0,003 \\
Demam tifoid & $3.0(1,05)$ & $3,3(1,02)$ & 0,5 \\
Infeksi dengue & $0.7(0,43)$ & $2,6(0,87)$ & $<0,001$ \\
Morbili / Varisella & $0.7(0,43)$ & $2,5(0,87)$ & $<0,001$ \\
ISPA atas & $2.0(0,91)$ & $2,9(0,68)$ & 0,001 \\
Infeksi virus & $0.0(0,00)$ & $2.0(2,11)$ & 0,001 \\
Diagnosis lain & $2.3(1,86)$ & $2,8(1,64)$ & 0,01 \\
\hline
\end{tabular}


Dari Gambar 1, dapat diringkas bahwa pemberian antibiotik sebelum ada hasil biakan dibenarkan bila terdapat paling tidak satu indikasi, yaitu ada sindroma respons peradangan sistemik (SRPS), ada fokus infeksi bakterial, atau usia kurang dari 3 bulan. Di luar ketiga kriteria tersebut maka pemberian antibiotik empirik tidak tepat.

Tabel 3 menunjukkan bahwa perbaikan bermakna dalam penggunaan antibiotik terjadi pada kelompok dengan fokus infeksi dan kelompok tanpa indikasi antibiotik. Sedangkan pada keadaan dengan SRPS justru terjadi penurunan kualitas. Seperti pada kasus pneumonia, hal ini disebabkan karena penggunaan kombinasi sefotaksim dan kloramfenikol (Skor 0).

\section{Peran pelatihan dan faktor-faktor lain terhadap kualitas penggunaan antibiotik}

Analisis dengan GEE terhadap faktor-faktor yang diduga turut mempengaruhi kualitas terapi antibiotik (Tabel 4) menunjukkan bahwa pelatihan memiliki pengaruh sangat bermakna $(p<0,001)$. Ada kecenderungan bahwa dokter perempuan lebih baik dalam menggunakan antibiotik $(\mathrm{OR}=2,1)$, tetapi hal ini tidak bermakna $(p>0,05)$.

Tabel 3. Perbandingan kualitas penulisan resep menurut indikasi antibiotik

\begin{tabular}{lccccc}
\hline Indikasi antibiotik & Skor kualitas & Pra-pelatihan & Pasca-pelatihan & Jumlah & $p$ \\
\hline Ada SRPS & 0 & 7 & 40 & 47 & $<0,05$ \\
& 1 & 25 & 27 & 52 & \\
2 & 6 & 11 & 17 & \\
Ada fokus infeksi & 3 & 35 & 44 & 79 & \\
& 4 & 186 & 197 & 383 & \\
& Rerata(SD) & $3.4(1,09)$ & $3,0(1,05)$ & & $<0,05$ \\
& 0 & 16 & 9 & 25 & $<0,001$ \\
& 1 & 44 & 13 & 57 & \\
Tidak ada indikasi antibiotik & 2 & 2 & 5 & 7 & \\
& 3 & 18 & 17 & 35 & \\
& 4 & 66 & 82 & 148 & $<0,001$ \\
& Rerata(SD) & $2.5(0,6)$ & $3,19(1,3)$ & & \\
& 0 & 226 & 113 & 339 & $<0,001$ \\
& 1 & 0 & 0 & 0 & \\
& 2 & 0 & 0 & 0 & \\
& 3 & 0 & 0 & 0 & \\
& 4 & 38 & 138 & 176 & \\
& Rerata(SD) & $0.5(1,14)$ & $2,0(1,2)$ & & $<0,001$ \\
\hline
\end{tabular}

Tabel 4. Analisis multivariat faktor-faktor yang mempengaruhi peningkatan kualitas pengelolaan antibiotik

\begin{tabular}{lccccc}
\hline Variabel & OR & \multicolumn{5}{c}{$95 \%$ CI } & $p$ \\
\hline Pelatihan & 4.1 & 1.9 & $\mathrm{~s} / \mathrm{d}$ & 9.0 & $<0,001$ \\
Pengetahuan & 1.0 & 1.0 & $\mathrm{~s} / \mathrm{d}$ & 1.1 & 0,73 \\
Sikap & 0.9 & 0.5 & $\mathrm{~s} / \mathrm{d}$ & 1.8 & 0,80 \\
Diskusi dengan supervisor & 1.0 & 0.2 & $\mathrm{~s} / \mathrm{d}$ & 3 & 0,97 \\
Diskusi dengan sejawat & 1.5 & 0.6 & $\mathrm{~s} / \mathrm{d}$ & 4.0 & 0,32 \\
Lama pendidikan & 1.6 & 0.8 & $\mathrm{~s} / \mathrm{d}$ & 3.4 & 0,18 \\
Jenis kelamin & 2.1 & 1.0 & $\mathrm{~s} / \mathrm{d}$ & 4.9 & 0,06 \\
\hline
\end{tabular}




\section{Pembahasan}

Dalam era meningkatnya resistensi kuman terhadap antibiotik, penggunaan antibiotik harus dikendalikan agar optimal.7 Rekomendasi WHO 2001 menyatakan bahwa untuk membatasi resistensi antibiotik, perbaikan kualitas penggunaan antibiotik harus menjadi aktivitas kunci. ${ }^{2}$ Masalah terbesar dalam penggunaan antibiotik ternyata bukanlah kesalahan dalam menentukan dosis, lama pemberian, atau jenis antibiotik, melainkan pada hal yang lebih mendasar, yaitu pengenalan ada tidaknya indikasi pemberian antibiotik. Frekuensi kesalahan dosis/rute/interval, lama, dan jenis antibiotik jauh lebih kecil. Hal ini karena umumnya hanya tersedia panduan penggunaan antibiotik untuk kasus yang telah jelas diagnosisnya, yang cukup rinci dosis, rute, interval, pilihan jenis dan lama terapinya. Sementara itu tidak tersedia panduan untuk kasus yang belum jelas diagnosisnya. Di negara berkembang seperti Indonesia, jenis pemeriksaan diagnostik terbatas, jangkauan asuransi kesehatan juga terbatas, sehingga penegakan diagnosis-pasti bisa tertunda hingga beberapa hari. Panduan untuk mengenali indikasi terapi antibiotik empirik yang tergantung pada keadaan klinis (bukan pada diagnosis) akan mempermudah dokter mengambil keputusan yang tepat tentang perlu tidaknya memberikan antibiotik sebelum ditegakkan diagnosis pasti. Banyak peneliti mendapatkan bahwa sebagian besar penyebab penggunaan antibiotik oleh dokter adalah karena kekhawatiran tidak mengenali adanya infeksi bakterial sehingga semua pasien dengan demam diberi antibiotik. Dokter merasa lebih baik keliru meresepkan antibiotik untuk penyakit viral dari pada keliru tidak memberikan antibiotik pada penyakit bakterial, tanpa memikirkan akibatnya pada problem munculnya resistensi antibiotik. Hal ini terutama terjadi pada kasus rawat jalan, karena umumnya sarana diagnostik terbatas, dan dokter tidak dapat memantau penderita setelah pasien pulang, ${ }^{8,10-14}$ tetapi hal ini mestinya tidak terjadi pada pasien rawat inap yang dapat dipantau 24 jam dan sarana diagnostiknya lebih lengkap.

Menurut Pomeranz AJ dkk, ${ }^{10}$ alasan yang benar untuk memberikan antibiotik pada kasus demam adalah ada tidaknya risiko tinggi infeksi bakterial berat atau derajat berat penyakit (menurut kriteria Yale), ada tidaknya fokus infeksi bakterial (kriteria Rochester), serta usia kurang dari tiga bulan. Hal di atas diadaptasi ke dalam materi pelatihan dalam penelitian ini, sebagai indikasi pemberian antibiotik apabila ada tanda-tanda SRPS (untuk menentukan derajat berat penyakit), ada fokus infeksi bakterial (meningitis, otitis media, pnemonia, gastroenteritis bakterial, infeksi saluran kemih, infeksi kulit, dan sebagainya), atau bila usia pasien kurang dari 3 bulan. Hapsari $\mathrm{dkk}^{6}$ telah meneliti bahwa dengan menerapkan algoritme tersebut ternyata jumlah penggunaan antibiotik dapat diturunkan secara sangat bermakna, tanpa meningkatkan morbiditas dan mortalitas pasien.

Pada pasien pediatri, umur merupakan salah satu pertimbangan untuk memberikan antibiotik. Beberapa senter pelayanan kesehatan menyarankan pemberian antibiotik empirik dalam 3 hari pertama bila pasien demam berusia kurang dari 2-3 bulan, karena pada usia tersebut, adanya fokus infeksi atau pun tanda-tanda infeksi bakterial yang berat (serious bacterial infection/ SBI) masih sulit terdeteksi, padahal risiko SBI pada usia tersebut cukup besar. ${ }^{8-12}$ Dalam penelitian ini ternyata semua pasien yang berusia kurang dari 3 bulan sudah menunjukkan tanda klinis dan laboratoris yang cukup jelas adanya penyakit berat atau fokus infeksi bakterial. Ini berarti penetapan batas umur 3 bulan sebagai dasar indikasi antibiotik perlu dievaluasi lagi. Begitu pula batas/kriteria lain mengenai perlunya pemberian antibiotik pada anak dengan demam yang sesuai dengan pola penyakit setempat perlu diteliti lebih lanjut, karena belum banyak data penelitian di Indonesia.

Tabel 3 memperlihatkan bahwa secara keseluruhan terjadi peningkatan kualitas penggunaan antibiotik pada fase pascapelatihan (rerata skor meningkat dari 2,0 menjadi 2,8). Ini merupakan perubahan yang positif, tetapi seharusnya peningkatan bisa mencapai 4,0 karena telah tersedia panduan berupa algoritme yang sederhana. Dengan kualitas penggunaan antibiotik yang tepat (skor 4), kesembuhan pasien dapat dicapai dengan waktu dan biaya optimal, ${ }^{6}$ dan problem resistensi dapat dicegah. Belum optimalnya skor yang dicapai pascapelatihan menunjukkan bahwa masih diperlukan upaya-upaya lain dan penguatan agar penggunaan antibiotik benar-benar bijak seperti yang diharapkan. Pada kasus demam tifoid kualitas penggunaan antibotik pada kedua periode tidak berbeda bermakna karena diagnosis dan panduan terapi untuk demam tifoid sudah jelas, meskipun demikian untuk demam tifoid seharusnya dapat mencapai skor 4.

Pada kasus pneumonia dan SRPS terjadi penurunan skor yang bermakna akibat penggunaan kombinasi 
antibiotik sefotaksim dan kloramfenikol. Panduan dari Sub Bagian Pulmonologi menetapkan bahwa antibiotik terpilih pada pneumonia sebelum ada hasil biakan adalah kombinasi ampisilin-kloramfenikol bila pasien berusia lebih dari tiga bulan, karena penyebab terbanyak pneumonia pada usia tersebut adalah H.influenzae dan S.pneumoniae. ${ }^{15}$ Beberapa dokter dalam penelitian ini mengganti ampisilin dengan sefotaksim karena kasus dianggap berat, sehingga kombinasi terapi menjadi sefotaksim dan kloramfenikol; dengan harapan mendapatkan efek terapeutik yang lebih baik. Padahal kedua obat ini justru bersifat antagonistik. Kombinasi kloramfenikol (bakteriostatik) dengan sefotaksim (bakterisid) justru mengurangi/menghilangkan efektivitas sefotaksim, menyebabkan problem resistensi (selective pressure) lebih besar, biaya lebih mahal, dan lebih toksik. ${ }^{16-17}$ Terapi sefotaksim atau kloramfenikol saja, atau benzil penisilin-gentamisin pada kasuskasus pneumonia berat akan lebih tepat dari pada kombinasi sefotaksim dengan kloramfenikol. ${ }^{18}$ Bila curiga telah terjadi resistensi penisilin, WHO merekomendasikan mengganti ampisilin dengan golongan penisilin-resisten-terhadap-betalaktamase (misalnya kloksasilin), atau kombinasi golongan penisilin dengan antibetalaktamase (sulbaktam, klavulanat), bukan dengan sefotaksim. ${ }^{18,19}$

\section{Pengaruh pelatihan dan faktor-faktor lain terhadap kualitas penggunaan antibiotik}

Analisis multivariat menunjukkan bahwa pelatihan berkontribusi besar terhadap perbaikan kualitas penggunaan antibiotik (Tabel 4). Besarnya pengaruh pelatihan terkait dengan karakteristik subjek yang relatif homogen, lokasi penelitian berupa unit rawat inap, serta sikap subjek tentang penggunaan antibiotik yang sejak sebelum pelatihan sudah "cenderung positif". Peningkatan kualitas penggunaan antibiotik masih jauh dari skor maksimal yang diharapkan, menunjukkan bahwa diperlukan upaya lain selain pelatihan. Faktor pengetahuan ternyata tidak memiliki kontribusi pada perbaikan kualitas penggunaan antibiotik. Pelatihan dalam hal ini tampaknya lebih berperan sebagai "momentum perubahan perilaku", bukan sebagai sarana penambah informasi. Menurut Lagerlov $\mathrm{P}^{20}$ perubahan pengetahuan memang tidak selalu diikuti dengan perubahan perilaku, yang umumnya terjadi terutama apabila ada desakan dari faktor eksternal yang memaksa subjek mengubah perilaku dulu walaupun sikapnya mungkin belum banyak berubah.

\section{Kesimpulan dan saran}

Kesalahan terbanyak dalam penggunaan antibiotik di Bagian Anak RS Dr Kariadi adalah penggunaan antibiotik yang tidak tepat indikasi. Penyusunan algoritme yang memberikan panduan tentang penggunaan antibiotik pada pasien berdasarkan beberapa data klinis dan laboratoris tanpa harus menunggu ditegakkannya diagnosis pasti dan pelatihan dokter dapat meningkatkan kualitas penggunaan antibiotik. Masih diperlukan upaya-upaya lain yang bersifat eksternal seperti pengulangan-pengulangan, umpan balik, dan penguatan dari pemangku kebijakan untuk mencapai hasil yang maksimal.

\section{Daftar Pustaka}

1. Blondeau JM. Appropriate antibiotic use - past lessons provide future direction. Dalam: Low DE, penyunting. International Congress and Symposium series 251. London: Royal Society of Medicine Press; 2001. h. 1-9.

2. WHO Department of Communicable Disease Surveillance and Response. WHO global strategy for containment of antimicrobial resistance. WHO Web site. [On Line] :URL. http://www.who.int/emc.

3. Craig WA. The future - can we learn from the past? Diagn. Microbiol. Infect. Dis 1997;27:49-53.

4. Gold HS, Mollering RC. Antimicrobioal drug resistance. N Engl J Med 1996;335:1445-53.

5. Winarto, Farida H. Prevalensi resistensi kuman yang diisolasi dari darah di RS Dr. Kariadi Semarang Juli - Desember 2002 terhadap antibiotik. Dalam: One day seminar on microbial infection recent strategies for prophilactic and management of antibioti usage. Semarang: Bagian Mikrobiologi FK Undip, 15-23.

6. Hapsari MM, Farida H, Keuter M, Van den Broek PJ, Hadi U, Herawati Y, Sachro ADBS. Penurunan Penggunaan Antibiotik pada Pasien Anak dengan Demam. Sari Pediatri 2006;8:16-24 .

7. Bauchner H, Pelton SI, Klein JO. Parents, physicians, and antibiotic use. Pediatrics 1999; 103:395-402.

8. Le Saux N, Pham B, Bjornson C, Pitter C. Antimicrobial use in febrile children diagnosed with respiratory 
tract illness in an emergency department. The Ped Infect Disease J 1999;18:1078-80.

9. Gyssens IC, Van den Broek PJ, Kullberg BJ, Hekster YA, Van der Meer JSUM. Optimizing antimicronial therapy, a method for antimicrobial drug use evaluation. J Antimicrob Chemother 1992;32:724-7.

10. Pomeranz JA, Busey SL, Sabnis SS, Behrman RE, Kliegman RM. Pediatric decision-making strategies. To accompany Nelson textbook of pediatrics. Edisi ke-16 .Toronto: WB Saunders; 2002:288-95.

11. Kramer MS. The young febrile child : Evidence-based diagnostic and therapeutic strategies. Emerg. Med. Pract 2000;2:1-24.

12. Rothrock SG, Green SM. Initial approach to febrile child. Didapat dari: http://www. clinicalconsensusreports. com/Secure/textbookarticles/Textbook/01_febrilechild.htm.

13. Cincinnati Children's Hospital Medical Center. Evidence based clinical practice guideline for Fever of uncertain source in infants 60 days of age or less.. Didapat dari: http://www. cincinnatichildrens.org/NR/rdonlyres/774D67CF-A010-4CA9AB58-2736117EF3C/O/feveruncertainsource1.pdf

14. Pichichero ME. Diynamics of antibiotic prescribing for children. JAMA 2002;287:3103-9.
15. Dowell SF, Marcy SM, Phillips WR, Gerber MA, Schwartz B. Principle judicious use of antimicrobial agents for pediatric upper respiratory tract infection. Pediatrics 1998;101:163-5.

16. Mandell B, Douglass D, Bennet. Principles and pratices in infectious disease. Edinburgh: Churcill Livingstone; 2000:223-307.

17. Asmar B, Prainito M, Dajani A. Antagoistic effect of chloramphenicol in combination with cefotaxime or ceftriaxone. Antimicrobial Agent and Chemotherapy 1998;32:1375-78.

18. Wolrd Health Organization. Emerging and and other communicable diseases, surveillance and control. Didapat dari: http://www.who.int/emc.

19. Vries TPGM, Henning RH, Hogerzeil HV, Fresle DA. Guide to good prescribing. A practical manual. Wolrd Health Organization, 1994:5-11. Didapat dari: http:// www.who-dap-94-11 en guide to good prescribing.pdf.

20. Lagerlov P, Loeb M, Andrew M, Hjordahl P. Improving doctor' prescribing behaviour through reflection on guidelines and prescription feedback: a randomised controlled study. Quality in Health Care 2000;9:5965. 